\title{
TINGKAT KONSISTENSI PEMUDA TANI TERHADAP TRANSFORMASI SEKTOR PERTANIAN DI KABUPATEN PONOROGO
}

\author{
Eri Yusnita Arvianti, Asnah, Anung Prasetyo \\ Universitas Tribhuwana Tunggadewi Malang \\ yusnitaarvianti@yahoo.co.id
}

\begin{abstract}
ABSTRAK
Kabupaten Ponorogo merupakan salah satu daerah di propinsi Jawa Timur yang menyumbang devisa terbesar melalui pengiriman TKI. Akibatnya terjadi pergeseran mata pencaharian dari petani menjadi bukan petani. Beberapa desa yang mengalami perubahan menjadi perkotaan adalah Mojorejo, Kemuning, Siwalan, Babadan, Demangan. Penelitian ini bertujuan untuk mengetahui tingkat konsistensi pemuda tani terhadap mata pencahariannya di Kabupaten Ponorogo. Metode yang digunakan adalah metode survei. Data dikumpulkan melalui teknik wawancara dengan para pemuda tani di lima desa. Teknik analisis data menggunakan purposive sample dengan 60 sampel. Konsistensi pemuda tani dideskripsikan melalui cara skoring dengan tiga kelas klasifikasi yaitu kelas tidak konsisten, kurang konsisten, dan konsisten. Hasil penelitian menunjukkan23 pemuda tani tidak konsisten. Pemuda yang tidak konsisten didominasi oleh para pemuda tani yang penguasaan lahannya sempit kurang dari $1.200 \mathrm{~m}^{2}$ dengan pendapatan kurang dari Rp. 10.000.000,00 per tahun. Pemuda tani yang kurang konsisten 15 orang didominasi oleh para pemuda tani yang memiliki pekerjaan lain diluar pertanian dan bukan penduduk asli. Sedangkan pemuda tani yang konsisten 22orang yang didominasi oleh para pemuda yang luas lahannya lebih dari $2.000 \mathrm{~m}^{2}$ dengan pendapatan tinggi lebih dari Rp. 15.000.000,00 per tahun.
\end{abstract}

Kata kunci: Pekerjaan, Pemuda Tani, Konsistensi

\section{CONSISTENCY LEVEL OF YOUNG FARMERS AGAINST TRANSFORMATION AGRICULTURAL SECTOR IN PONOROGO}

\begin{abstract}
Ponorogo is one area in East Java province which contributes for the largest foreign exchange through workers sending. As the result, there is a shift in the livelihood of farmers into non farmers. Some villages were transformed into urban are Mojorejo, Kemuning, Siwalan, Babadan, Demangan. This study aims to determine the level of consistency to the livelihood of the peasant youth in Ponorogo. The method used was a survey method. Data were collected through interviews in five villages of young farmes. Data were analyzed using purposive sample with 60 samples. Consistency young farmers described by scoring three classified classes consisting consistent grade, less consistent, and consistent. The results showed that 23 young farmers is not consistent. Young farmers who do not consistent was dominated by young farmers owning land less than 1.200 $\mathrm{m}^{2}$ with an income of less than Rp. 10.000.000,00 in year. 15 less consistent young farmers were dominated by the young farmers who have other jobs outside the agricultural sector and non-indigenous villager. While the other 22 consistent young farmers were dominated by the youth with land
\end{abstract}


owning more than $2.000 \mathrm{~m}^{2}$ with high income more than $\mathrm{Rp}$. 15.000.000,00 in year.

Keywords: Employment, Young Farmers, Consistency

\section{PENDAHULUAN}

Negara Indonesia adalah negara agraris yang memiliki peran bukan hanya menghasilkan produk-produk domestik. Pertanian memiliki potensi yang besar untuk menghasilkan devisa baik secara langsung melalui ekspor bahan baku atau komoditas pertanian primer, tetapi juga yang lebih besar potensinya untuk masa mendatang adalah menghasilkan devisa melalui ekspor produk hasil olahan. Hasil-hasil pertanian merupakan salah satu sumber pendapatan devisa negara.

Sebagian besar penduduk Indonesia bekerja pada sektor pertanian dan hidup di pedesaan. Menurut Zanses (2015), berdasarkan teknologi usaha taninya maka sektor pertanian terbagi menjadi desa yang bercocok tanam di ladang dan desa yang bercocok tanam di sawah. Kehidupan di perkotaan bergantung pada sektor pertanian yang berada di desa.

Sektor pertanian dalam kaitannya dengan sektor yang penting dalam pembangunan tidak terlepas dari masalah, diantarannya terdapat pergeseran kesempatan kerja di pertanian. Dapat dilihat bahwa pekerja di sektor pertanian rata-rata berusia tua (40 tahun ke atas) sedangkan tenaga kerja berusia muda lebih memilih bekerja sebagai buruh industri daripada buruh tani. Alasan tenaga kerja berusia tua lebih banyak dikarenakan tenaga kerja ini kurang atau tidak memiliki keterampilan. Pengetahuan yang dimiliki petani terbatas pada apa yang dapat mereka rasakan secara langsung, biasanya melalui pengamatan dan apa yang bisa mereka pahami dengan konsep mereka sendiri. Konsep ini muncul dari pengalaman mereka pada masa lalu yaitu dari nenek moyang mereka sebagai petani. Oleh karena itu, kemungkinan mereka kesulitan untuk mengartikan proses yang baru atau proses yang berpengaruh secara perlahan-lahan atau secara tidak langsung. Selain itu yang lebih utama adalah karena pekerjaan petani sudah mengakar pada diri mereka dan mendapatkan ketentraman di dalam pekerjaan petani tersebut.

Para pemuda tani di desa memandang pekerjaan petani menjadi bagian generasi tua yang sejak semula sudah menekuni bidang pertanian.Pemuda di pedesaan menghindari bekerja di sektor pertanian karena memandangnya sebagai pekerjaan yang kotor dan melelahkan (Hamyana, 2014).

Meningkatnya jumlah penduduk pedesaan sementara luasan lahan berkurang karena pemukiman, membuat pemuda susah dalam mencari pekerjaan di sektor pertanian. Mereka yang sebelumnya mempunyai lahan, kemudian menjualnya dan menjadi buruh tani. Keadaan ini menambah jumlah buruh tani yang ada, sementara lahan pertanian tetap akibatnya upah buruh tani menjadi turun. Penurunan upah tersebut tentunya membuat pemuda berfikir untuk mencari pekerjaan yang lebih baik di luar sektor pertanian.

Kondisi minimnya keterlibaatan pemuda pada sektor pertanian dipengaruhi oleh penerapan teknologi pertanian. Penerapan teknologi baru pada sektor pertanian dilakukan untuk mengimbangi pertumbuhan penduduk yang cepat guna tercapainya peningkatan poduktivitas pertanian. Namun, penerapan tekologi ini memiliki akibat yaitu pengurangan atau penciutan lapangan pekerjaan yang dialami oleh petani miskin di pedesaan (Arvianti, 2015). 
Penduduk muda cenderung memilih upah yang lebih tinggi dan memilih menjadi TKI atau bekerja di sektor lain. Hal ini memberikan efek negatif yaitu banyak lahan pertanian yang digusur secara paksa untuk dijadikan daerah perindustrian, ataupun perumahan. Sehingga pola mata pencaharian penduduk desa pun mengalami perubahan (Rauf, 2013).

Kecamatan kota Ponorogo adalah salah satu kecamatan di Kabupaten Ponorogo yang berbatasan langsung dengan kota madya Madiun. Sebagai daerah yang merupakan daerah lumbung TKI di Jawa Timur, Kabupaten Ponorogo ini mengalami perubahan struktur yang mempunyai sifat kekotaan. Ciri tersebut ditunjukkan dari banyaknya perubahan struktur perumahan desa menjadi rumah modern, dan mulai berkurangnya lahan pertanian. Jumlah penduduk cukup tinggi, yaitu 863.900 jiwa dan sebagian besar bekerja menjadi TKI, yaitu 4039 orang (BPS Ponorogo, 2014).

Kecamatan kota Ponorogo ada beberapa desa yang terdapat penduduk bermata pencaharian sebagai petani. Desa-desa tersebut antara lain Desa yaitu Mojorejo, Kemuning, Siwalan, Babadan, Demangan. Dari mata pencaharian sebagai petani tersebut dibedakan menjadi sawah irigasi dan sawah tadah hujan seperti pada Tabel 1 berikut.

Tabel 1

Jenis Lahan Sawah di Kecamatan Kota Ponorogom (ha)

\begin{tabular}{|c|c|c|c|}
\hline \multirow{2}{*}{ Desa } & \multicolumn{2}{|c|}{ Jenis Pertanian } & \multirow[b]{2}{*}{ Jumlah } \\
\hline & Irigasi & Tadah hujan & \\
\hline Mojorejo & 1423 & 6 & 1429 \\
\hline Kemuning & 902 & 218 & 1120 \\
\hline Siwalan & 1338 & 23 & 1361 \\
\hline Babadan & 2957 & 103 & 3060 \\
\hline Demangan & 1539 & 23 & 1562 \\
\hline
\end{tabular}

Sumber: BPS Ponorogo, 2014

Fokus penelitian penulis di sini adalah pertanian sawah yang berada di 5 desa, yaitu Mojorejo, Kemuning, Siwalan, Babadan, Demangan Kelima desa tersebut mata pencahariannya adalah bertani dan penduduknyapun juga banyak yang berangkat menjadi TKI di luar negeri. Kecenderungan ini akan berakibat pada sektor pertanian. Tingkat konsistensi masyarakat terutama pemuda desa untuk tetap memilih mata pencaharian sebagai pemuda tani adalah hal menarik untuk diulas dan dikaji. Karena itu, peneliti melakukan penelitian yang bertujuan untuk mengetahui tingkat konsistensi pemuda tani terhadap transformasi di sektor pertanian di Kabupaten Ponorogo.

\section{METODE PENELITIAN}

Jenis penelitian yang digunakan adalah penelitian survei. Penelitian ini dimaksudkan untuk memperoleh fakta-fakta dan gejala-gejala yang ada dan mencari keterangan-keterangan dan gambaran secara jelas tentang eksistensi petani di daerah penelitian.

Penelitian ini dilakukan di 5 desa di Kecamatan Kota Ponorogo yaitu di Mojorejo, Kemuning, Siwalan, Babadan, Demangan. Penelitian ini bertujuan untuk mengetahui Kabupaten Ponorogo yang memiliki penduduk bermata pencaharian sebagai pemuda tani. Pemilihan lokasi ini berdasakan data yang diperoleh dari BPS yang menunjukkan jumlah pemuda tani di lima desa tersebut adalah basisnya TKI dan basisnya lahan pertanian. 
Populasi dalam penelitian ini adalah seluruh penduduk di Kecamatan Kota Ponorogo yang bermata pencaharian sebagai buruh tani padi. Dari 568 penduduk dimana 150 sebagai petani padi. Jadi, populasi dalam penelitian ini adalah 150 petani padi.

Sampel dalam penelitian ini adalah penggunaan sampel secara purposif, artinya sampel diambil berdasarkan pertimbangan peneliti. Pengambilan sampel secara purposif karena data sekunder yang menunjukkan jumlah pemuda tani di Kabupaten Ponorogo dan setelah melakukan observasi di lapangan, maka peneliti menentukan jumlah sampel sebanyak 60 responden dari 75 orang pemuda yang mata pencaharian utamanya sebagai pemuda tani jumlah populasi responden sebanyak 150 orang. Artinya, mata pencaharian sebagai petani bukanlah mata pencaharian sampingan.

Pengambilan sampel dalam penelitian ini mengambil 5 Desa yang ada di Ponorogo karena hanyak ada 5 desa yang terdapat penduduk bermata pencaharian sebagai petani. 5 Desa tersebut meliputi Desa yaitu Mojorejo, Kemuning, Siwalan, Babadan, Demangan. Sedangkan teknik pengambilan sampelnya menggunakan purposif secara proporsional untuk setiap desa sebagai berikut:
Mojorejo $\quad: 20 / 150 \times 75=10$ responden
Kemuning $: 61 / 150 \times 75=30$ responden
Siwalan $: 23 / 150 \times 75=11$ responden
Babadan $: 6 / 150 \times 75=3$ responden
Demangan : $12 / 150 \times 75=6$ responden

Jenis dan sumber data yang digunakan meliputi data primer dan data sekunder. Dalam penelitian ini, data primer merupakan sumber data yang dikumpulkan berdasarkan hasil wawancara langsung dengan responden (penduduk yang bekerja sebagai pemuda tani di Kecamatan Kota Ponorogo, Kabupaten Ponorogo). Wawancara tersebut dilakukan menggunakan instrument wawancara dengan beberapa pertanyaan. Pertanyaan tersebut dikembangkan dari variabel penelitian yang meliputi:

1. Umur

2. Tingkat Pendidikan

3. Luas Penguasan Lahan

4. Pendapatan dari Hasil Kegiatan Pertanian

5. Pendapatan di Luar Pertanian

6. Pekerjaan Lain

7. Jarak rumah dengan lahan yang diusahakan

8. Status Kependudukan

9. Keterampilan lain yang dimiliki

Data sekunder merupakan pendukung atau pelengkap data primer yang diperoleh dari instansi-instansi terkait. Dalam penelitian ini, data sekunder meliputi data kependudukan, data monografi, serta BPS Ponorogo. Teknik pengumpulan data digunakan untuk mendapatkan data-data yang baik, relevan, dan akurat sehingga dapat menunjang kelancaran dalam penelitian. Adapun teknik pengumpulan data yang digunakan dalam penelitian ini meliputi wawancara dokumentasi dan observasi.

Teknik wawancara dilakukan dengan cara mengadakan tanya jawab langsung kepada responden sesuai dengan instrument wawancara. 
Dokumentasi disini didapat dari data-data pendukung penelitian. Dilakukan untuk mengumpulkan data pelengkap untuk memperkuat data-data yang sudah ada dan untuk memperkuat data pelengkap yang diperoleh dari lapangan. Adapun data yang diperoleh dalam dokumentasi ini adalah data monografi dan foto-foto hasil penelitian.

Observasi dalam penelitian ini, yaitu melihat kondisi yang ada di lapangan, melakukan survei dan mengkroscek dari hasil wawancara dan dokumentasi. Dalam observasi ini, data yang diperoleh berupa data primer hasil wawancara dan pengamatan untuk mengetahui karakteristik Kabupaten Ponorogo.

Dalam penelitian ini, teknik analisis yang digunakan adalah deskriptif kuantitatif. Deskripsi mengenai konsistensi pemuda tani diperoleh dengan cara dibuat kelas-kelas sebagai berikut.

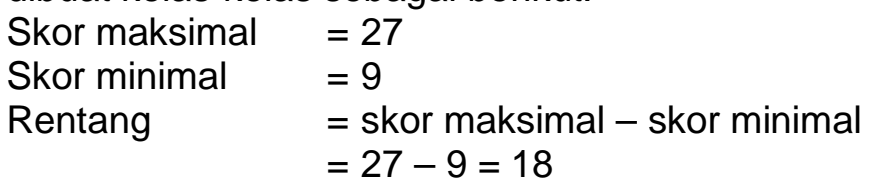

Banyak kelas $9(k)=3$ (ditentukan oleh peneliti)

$\mathrm{p}$ (panjang kelas) $=$ Rentang banyak kelas : 18/3-6

Nilai ujung bawah kelas interval $=9$ (nilai terendah)

Selanjutnya, klasifikasi tingkat konsisten petani dengan mata pencaharian sebagai pemuda tani di kecamatan Kota Kabupaten Ponorogo dapat dilihat pada berikut.

Tabel 2

Tingkat Konsistensi Pemuda Tani

\begin{tabular}{lc}
\hline Kategori & Skor \\
\hline Konsisten & $22-27$ \\
Kurang Konsisten & $15-21$ \\
Tidak Konsisten & $8-14$
\end{tabular}

Sumber: Muksin, 2009

\section{HASIL DAN PEMBAHASAN}

Hasil penelitian ini diperoleh penelitian melalui wawancara berdasarkan instrument wawancara yang mencakup pertanyaan-pertanyaan yang dikembangkan dari variabel penelitian yang dilakukan di lima desa/kelurahan di Kecamatan Kota Ponorogo, yaitu Desa/Kelurahan yaitu Mojorejo, Kemuning, Siwalan, Babadan, Demangan. Penelitian ini bertujuan untuk mengetahui. Pertanyaan tersebut meliputi umur, tingkat pendidikan, luas penguasaan lahan, pendapatan dari hasil kegiatan pertanian, pendapatan di luar pertanian, pekerjaan lain, jarak rumah dengan lahan yang diusahakan, status kependudukan, dan keterampilan lain yang dimiliki.

\section{Umur}

Umur dihitung dari lahir sampai pada saat penelitian dilakukan. Dari hasil penelitian di lapangan diperoleh informasi rentangan umur pemuda tani antara 20 tahun sampai 40 tahun. Kemudian dilakukan pengklasifikasian umur dengan persen seperti pada Tabel 3. 
Tabel 3

Persentase Umur Pemuda Tani

\begin{tabular}{clcc}
\hline No & Rentang Umur & Jumlah & Persentase (\%) \\
\hline 1 & $<30$ tahun & 15 & 25 \\
2 & $30-39$ tahun & 27 & 45 \\
3 & $>40$ tahun & 18 & 30 \\
\hline Total & & 60 & 100 \\
\hline
\end{tabular}

Sumber: Data Primer Diolah, 2015

Dari 60 responden yang telah penulis wawancarai, sebanyak 15 responden berusia kurang dari 30 tahun atau sekitar 25\%. Dan yang berumur antara 30 sampai 39 tahun berjumlah 27 responden atau sekitar $45 \%$. Sedangkan responden yang berusia lebih dari 40 tahun berjumlah 30 responden atau sekitar 30\%. Dari tabel tersebut dapat diketahui bahwa jumlah responden terbanyak adalah yang berusia antara 30 sampai 39 tahun dengan jumlah 27 responden atau $45 \%$.

\section{Tingkat Pendidikan}

Tingkat pendidikan yang didasarkan pada pendidikan terakhir yang ditempuh. Pendidikan terakhir yang ditempuh pemuda tani di Ponorogo terendah adalah tidak lulus SD dan tertinggi adalah D3. Kemudian diklasifikasikan menjadi tiga kelas, yaitu pendidikan terakhir SMP, kurang dari SMP, dan lebih dari SMP. Kelas-kelas tersebut kemudian diprosentasikan yang dapat dilihat pada Tabel 4.

\section{Tabel 4}

Persentase Tingkat Pendidikan Pemuda Tani

\begin{tabular}{clcc}
\hline No & Tingkat Pendidikan & Jumlah & Persentase $(\%)$ \\
\hline 1 & SMP & 16 & 27 \\
2 & SMP-SMA & 36 & 60 \\
3 & >SMA & 8 & 13 \\
\hline Total & & 60 & 100 \\
\hline
\end{tabular}

Sumber: Data Primer Diolah, 2015

Dari 60 responden yang diwawancarai, tingkat pendidikan terakhir yang lebih dari SMA sebanyak 8 responden atau sekitar 13\%. Dan responden yang pendidikan terakhir SMP-SMA sebanyak 36 responden atau sekitar $60 \%$. Sedangkan responden yang pendidikan terakhir kurang SMP sebanyak 16 responden atau sekitar $27 \%$. Berdasarkan wawancara tersebut, maka jumlah responden terbanyak adalah responden dengan pendidikan terakhir antara SMPSMA sebanyak 36 responden atau sekitar $60 \%$.

\section{Penguasaan Lahan Luas}

Pemuda tani di lima desa lokasi penelitian memiliki luas penguasaan lahan yang berbeda-beda. Luas penguasaan lahan pemuda tani, dari hasil wawancara adalah $800 \mathrm{~m}^{2}$ sampai $3.500 \mathrm{~m}^{2}$. Dan data tersebut kemudian dipresentasikan sesuai kelasnya. Persentase penguasaan lahan dapat dilihat pada Tabel 5. 


\section{\begin{tabular}{l|l} 
& Agriekonomika, ISSN 2301-9948 \\
April, 2016 & e ISSN 2407-6260
\end{tabular} \\ Volume 5, Nomor 1}

Tabel 5

Persentase Luas Penguasaan Lahan

\begin{tabular}{clcc}
\hline No & Luas Lahan $\left(\mathrm{m}^{2}\right)$ & Jumlah & Persentase $(\%)$ \\
\hline 1 & $<1.200$ & 19 & 31 \\
2 & $1200-2.000$ & 34 & 57 \\
3 & $>2.000$ & 7 & 12 \\
\hline Total & & 60 & 100 \\
\hline
\end{tabular}

Sumber: Data Primer Diolah, 2015

Pemuda tani dengan penguasaan lahan kurang dari $1.200 \mathrm{~m}^{2}$ sebanyak 19 responden atau sekitar $31 \%$. Penguasaan lahan antara 1.200 sampai $2.000 \mathrm{~m}^{2}$ sebanyak 34 responden atau sekitar $57 \%$. Sedangkan pemuda tani yang mempunyai luas penguasaan lahan lebih dari $2.000 \mathrm{~m}^{2}$ sebanyak 7 responden atau sekitar $12 \%$. Dari wawancara tersebut dapat diketahui bahwa jumlah responden terbanyak adalah pemuda tani dengan penguasaan lahan antara 1.200 sampai $2.000 \mathrm{~m}^{2}$ sebanyak 34 responden atau sekitar $57 \%$.

\section{Pendapatan dari Hasil Kegiatan Pertanian}

Pendapatan dari hasil kegiatan pertanian adalah pendapatan pemuda tani yang diperoleh dari mata pencahariannya. Perhitungan pendapatannya dihitung rata-rata pertahun. Dari penelitian diperoleh angka pendapatan terendah sebesar Rp 3.500.000,- dan angka tertinggi sebesar Rp 20.000.000,-. Persentase pendapatan dari hasil kegiatan pertanian terdapat pada tabel berikut.

Tabel 6

Persentase Pendapatan dari Hasil Kegiatan Pertanian

\begin{tabular}{clcc}
\hline No & \multicolumn{1}{c}{ Pendapatan } & Jumlah & Persentase $(\%)$ \\
\hline 1 & $<10.000 .000$ & 22 & 36,7 \\
2 & $10.000 .000-15.000 .000$ & 24 & 40 \\
3 & $>15.000 .000$ & 14 & 23,3 \\
\hline Total & & 60 & 100 \\
\hline
\end{tabular}

Sumber: Data Primer Diolah, 2015

Dari Tabel 6, dapat dilihat bahwa pemuda tani yang dari hasil kegiatan pertaniannya kurang dari Rp 10.000.000,- per tahun berjumlah 22 responden atau sekitar $36,7 \%$. Pendapatan antara Rp 10.000.000,- sampai Rp 15.000.000,berjumlah 24 responden atau $40 \%$. Sedangkan yang memiliki pendapatan dari hasil kegiatan pertanian lebih dari Rp 15.000.000.- berjumlah 14 responden atau sekitar $23,3 \%$. Sehingga, jumlah terbanyak adalah pemuda tani tani yang memiliki pendapatan dari hasil kegiatan pertanian antara $\mathrm{Rp} 10.000 .000$,- sampai Rp 15.000.000,- yang berjumlah 24 responden atau sekitar $40 \%$.

\section{Pendapatan di Luar Pertanian}

Pendapatan diluar pertanian diperoleh dari pendapatan yang dihasilkan dari kegiatan atau pekerjaan lain selain sebagai petani seperti TKI atau pabrik atau berdagang. Pendapatan diluar pertanian terendah adalah $\mathrm{Rp} 500.000,-$ dan tertinggi sebesar Rp 15.00.000,-. Dari informasi tersebut dikelompokkan menjadi 3 kelas. Karena sebagian petani ada yang tidak memiliki pekerjaan lain di luar pertanian sehingga tidak memiliki pendapatan lain maka diikutkan dalam kelas terendah. Persentase pendapatan di luar pertanian terdapat pada Tabel 7. 
Tabel 7

Persentase Pendapatan di Luar Pertanian

\begin{tabular}{clcc}
\hline No & \multicolumn{1}{c}{ Pendapatan } & Jumlah & Persentase (\%) \\
\hline 1 & Lebih dari1.000.000 & 13 & 21,7 \\
2 & $600.000-1.000 .000$ & 15 & 25 \\
3 & Tidak ada & 32 & 53,30 \\
\hline Total & & 60 & 100 \\
\hline
\end{tabular}

Sumber: Data Primer Diolah, 2015

Dari Tabel 7, dapat diketahui bahwa pemuda tani yang memiliki pendapatan di luar pertanian lebih dari Rp 1.000.000 sebanyak 13 responden atau sekitar $21,7 \%$. Pendapatan di luar pertanian antara Rp 600.000 sampai Rp 1000.000 berjumlah 15 responden atau sekitar 25\%. Sedangkan yang tidak memiliki pendapatan diluar pertanian berjumlah 32 responden atau sekitar $53,3 \%$.Sehingga data diketahui bahwa pemuda tani yang mempunyai pendapatan di luar pertanian terbanyak adalah pemuda tani yang tidak memiliki pendapatan diluar pertanian dengan jumlah responden sebanyak 32 responden atau sekitar $53,3 \%$.

\section{Pekerjaan Lain}

Pekerjaan lain disini adalah ada atau tidaknya pekerjaan lain selain sebagai petani muda. Jenis pekerjaan lain selain sebagai petani meliputi beberapa sektor. Dalam pengklasifikasian pekerjaan lain-lain disini dibedakan menjadi pekerjaan lain di sektor formal, informal, dan buruh tani yang tidak memiliki pekerjaan lain. Persentase pekerjaan lain dapat dilihat pada Tabel 8.

Tabel 8

Persentase Pekerjaan Lain

\begin{tabular}{clcc}
\hline No & Pekerjaan Lain & Jumlah & Persentase (\%) \\
\hline 1 & Formal & 7 & 11,7 \\
2 & Informal & 26 & 43,3 \\
3 & Tidak ada & 27 & 45 \\
\hline Total & & 60 & 100
\end{tabular}

Sumber: Data Primer Diolah, 2015

Pekerjaan lain pemuda tani di sektor formal berjumlah 7 responden atau sekitar $11,7 \%$. Untuk sektor informal berjumlah 26 responden atau sekitar 43,3\%. Sedangkan pemuda tani yang tidak mempunyai pekerjaan lain berjumlah 27 responden atau sekitar $45 \%$. Sehingga dapat diketahui bahwa untuk variabel pekerjaan lain, jumlah terbanyak adalah pemuda tani yang tidak memiliki pekerjaan lain sebanyak 27 responden atau sekitar $45 \%$.

\section{Jarak Rumah dengan Lahan yang Diusahakan}

Jarak rumah dengan lahan yang diusahakan mempengaruhi konsistensi pemuda tani. Semakin dekat dengan lahan pertanian, konsistensinya akan semakin tingi. Pada variabel jarak rumah dengan lahan yang diusahakan diperoleh informasi bahwa jarak terdekat adalah $200 \mathrm{~m}$ dan jarak terjauh adalah 5 $\mathrm{km}$. kemudian diklasifikasikan menjadi tiga kelas yang meliputi jarak lebih dari 2 $\mathrm{km}$, antara 1 sampai $2 \mathrm{~km}$, dan kurang dari $1 \mathrm{~km}$. Persentase jarak rumah dengan lahan yang diusahakan terdapat pada Tabel 9. 
Tabel 9

Jarak dengan Lahan yang Diusahakan

\begin{tabular}{rccc}
\hline No & Jarak & Jumlah & Persentase (\%) \\
\hline 1 & $>2 \mathrm{~km}$ & 22 & 36,7 \\
2 & $1-2 \mathrm{~km}$ & 28 & 46,7 \\
3 & $<1 \mathrm{~km}$ & 10 & 16,6 \\
\hline Total & & 60 & 100
\end{tabular}

Sumber: Data Primer Diolah, 2015

\section{Status Kependudukan}

Status kependudukan membedakan apakah penduduk asli atau pendatang yang dihitung berdasarkan lamanya tinggal di daerah penelitian dan diklasifikasikan menjadi penduduk yang tinggal di daerah penelitian kurang dari 20 tahun, antara 20 tahun sampai 30 tahun, dan lebih dari 30 tahun. Karena dari wawancara diperoleh informasi bahwa lama tinggal penduduk di daerah penelitian minimal 15 tahun dan maksimal 70 tahun. Persentase status kependudukan terdapat pada Tabel 10. Dari Tabel 9, dapat diketahui bahwa jarak dari rumah menuju lahan yang diusahakan lebih dari $2 \mathrm{~km}$ berjumlah 22 responden atau sekitar $36,7 \%$. Untuk jarak dari rumah dengan lahan yang diusahakan antara 1 sampai $2 \mathrm{~km}$ berjumlah 28 responden atau sekitar 46,7\%. Sedangkan jarak dari rumah dengan lahan yang diusahakan kurang dari $1 \mathrm{~km}$ berjumlah 10 responden atau sekitar $16,6 \%$.

Tabel 10

Status Kependudukan Pemuda Tani

\begin{tabular}{cccc}
\hline No & Lama tinggal & Jumlah & Persentase (\%) \\
\hline 1 & $>20$ tahun & 18 & 30 \\
2 & $20-30$ tahun & 15 & 25 \\
3 & $>30$ tahun & 27 & 45 \\
\hline Total & & 60 & 100 \\
\hline
\end{tabular}

Sumber: Data Primer Diolah, 2015

Pemuda tani yang tinggal di daerah penelitian kurang dari 20 tahun berjumlah 18 responden atau sekitar 30\%. Untuk pemuda tani yang tinggal di daerah penelitian antara 20 sampai 30 tahun berjumlah 15 responden atau sekitar $25 \%$. Sedangkan pemuda tani yang tinggal di daerah penelitian lebih dari 30 tahun berjumlah 27 responden atau sekitar $45 \%$.Sehingga dapat diketahui bahwa jumlah pemuda tani terbanyak adalah pemuda tani yang tinggal di daerah penelitian lebih dari 30 tahun dengan jumlah 27 responden atau sekitar $45 \%$.

\section{Keterampilan Lain yang Dimiliki}

Keterampilan lain yang dimiliki adalah keahlian lain selain bertani. Di Ponorogo, terdapat beberapa pemuda tani yang memiliki keterampilan lain. Sehingga untuk pengklasifikasian dibedakan menjadi keterampilan dibidang jasa, keterampilan dibidang perdagangan, dan buruh tani yang tidak memiliki keterampilan lain. Persentase keterampilan lain. Persentase keterampilan lain yang dimiliki terdapat pada Tabel 11. 
Tabel 11

Keterampilan Lain yang Dimiliki

\begin{tabular}{clcc}
\hline No & Keterampilan Lain & Jumlah & Persentase (\%) \\
\hline 1 & Jasa & 6 & 10 \\
2 & Perdagangan & 31 & 51,7 \\
3 & Tidak ada & 23 & 38,3 \\
\hline Total & & 60 & 100 \\
\hline
\end{tabular}

Sumber: Data Primer Diolah, 2015

Keterampilan lain yang dimiliki pemuda tani di bidang jasa berjumlah 6 responden atau sekitar $10 \%$. Untuk keterampilan lain dibidang perdagangan berjumlah 31 responden atau sekitar $51,7 \%$. Sedangkan pemuda tani yang tidak memiliki keterampilan lain berjumlah 23 responden atau sekitar $38,3 \%$. Sehingga dapat diketahui bahwa jumlah terbanyak adalah pemuda tani yang tidak memiliki keterampilan lain dengan jumlah 31 responden atau sekitar $51,7 \%$.

Tingkat konsistensi pemuda tani di lima desa Kabupaten Ponorogo yang meliputi pemuda tani yang tidak konsisten berjumlah 23 pemuda tani atau sekitar $38,3 \%$. Yang kurang konsisten berjumlah 15 orang sekitar 25\%. Sedangkan pemuda tani yang konsisten berjumlah 22 orang atau sekitar $36,7 \%$.

\section{Desa Mojorejo}

Desa Mojorejo terdapat buruh tani.Dari 20 populasi pemuda tani tersebut diambil 10 pemuda tani sebagai responden. Kemudian dilakukan wawancara dengan pemuda tani yang berjumlah 10 responden sebagai sampel. Penskoran Desa Mojorejo terdapat pada Tabel 12.

Tabel 12

Penskoran Desa Mojorejo

\begin{tabular}{ccc}
\hline No. Responden & Skor & Kategori \\
\hline 1 & 16 & Kurang konsisten \\
2 & 13 & Tidak konsisten \\
3 & 16 & Tidak konsisten \\
4 & 21 & Konsisten \\
5 & 13 & Tidak konsisten \\
6 & 24 & Konsisten \\
7 & 14 & Tidak konsisten \\
8 & 23 & Tidak konsisten \\
9 & 11 & Konsisten \\
10 & 23 & Tidak konsisten \\
\hline
\end{tabular}

Sumber: Data Primer Diolah, 2015

Dari 10 sampel yang diwawancari menunjukkan kondisi pemuda tani yang tidak konsisten konsisten dan kurang konsisten.Lahan yang dikelola pemuda tani dari kedua sampel tersebut adalah milik pribadi dan sebagian ada yang milik investor.

Keadaan tersebut dipengaruhi oleh keadaan Desa Mojorejo yang sebagian besar lahannya ada yang masih dibudidayakan ada juga yang sudah beralih fungsi ke perumahan.Selain itu, yang menyebabkan ketidak konsistenan pemuda tani karena pendapatan yang kecil dari hasil pertanian, mereka tergiur oleh pekerjaan ke kota yaitu di Surabaya. 


\section{Desa Kemuning}

Desa Kemuning terdapat 61 pemuda tani. Dari populasi totali tersebut diambil 30 responden sebagai sampel. Kemudian dilakukan wawancara dengan pemuda tani sejumlah 30 responden sebagai sampel.Penskoran Desa Kemuning terdapat pada Tabel 13.

Tabel 13

Penskoran Desa Kemuning

\begin{tabular}{ccc}
\hline No. Responden & Skor & Kategori \\
\hline 11 & 24 & Konsisten \\
12 & 16 & Tidak konsisten \\
13 & 23 & Konsisten \\
14 & 12 & Tidak konsisten \\
15 & 23 & Konsisten \\
16 & 20 & Kurang konsisten \\
17 & 19 & Kurang konsisten \\
18 & 18 & Kurang konsisten \\
19 & 21 & Kurang konsisten \\
20 & 20 & Kurang konsisten \\
21 & 21 & Kurang konsisten \\
22 & 23 & Konsisten \\
23 & 23 & Konsisten \\
24 & 21 & Kurang konsisten \\
25 & 14 & Tidak konsisten \\
25 & 14 & Tidak konsisten \\
26 & 25 & Konsisten \\
27 & 12 & Tidak konsisten \\
28 & 22 & Konsisten \\
29 & 24 & Konsisten \\
30 & 25 & Konsisten \\
31 & 19 & Kurang konsisten \\
32 & 18 & Kurang konsisten \\
33 & 21 & Kurang konsisten \\
34 & 20 & Kurang konsisten \\
35 & 21 & Kurang konsisten \\
36 & 23 & Konsisten \\
37 & 23 & Konsisten \\
38 & 21 & Kurang konsisten \\
39 & 14 & Tidak konsisten \\
40 & 13 & \\
\hline & &
\end{tabular}

Sumber: Data Primer Diolah, 2015

Dari 30 responden yang diwawancari, masing-masing responden memiliki konsistensi yang berbeda. 11 responden masih konsisten dari 30 orang responden yang lain. Hal ini berarti masyaratakt (pemuda tani) di desa kemuning masih mengandalkan lahan pertanian di wilayahnya untuk tetap konsisten ditanami padi, kalaupun disewakan masih tidak beralih fungsi kelahan non pertanian.

Hal ini menunjukkan bahwa di Desa Kemuning jumlah pemuda taninya paling banyak dibanding kelima desa lainnya dan mereka masih sebagai tenaga produktif. 


\section{Kelurahan Siwalan}

Populasi di Kelurahan Siwalan adalah 23 orang pemuda.Dari 23 populasi tersebut diambil 11 orang responden sebagai sampel. Kemudian dilakukan wawancara terhadap 11 sampel tersebut. Penskoran Kelurahan Siwalan terdapat pada Tabel 14.

\section{Tabel 14}

Penskoran Kelurahan Siwalan

\begin{tabular}{ccc}
\hline No. Responden & Skor & Kategori \\
\hline 41 & 16 & Tidak konsisten \\
42 & 21 & Konsisten \\
43 & 13 & Tidak konsisten \\
44 & 24 & Konsisten \\
45 & 14 & Tidak konsisten \\
46 & 23 & Tidak konsisten \\
47 & 11 & Konsisten \\
48 & 23 & Tidak konsisten \\
49 & 16 & Kurang konsisten \\
50 & 13 & Tidak konsisten \\
51 & 16 & Tidak konsisten
\end{tabular}

Sumber: Data Primer Diolah, 2015

Dari wawancara dengan responden di Kelurahan Siwalan menunjukkan bahwa terdapat 7 responden yang tidak konsisten terhadap mata pencahariannya. Ada 3 orang yang konsisten sementara 1 responden kurang konsisten. Lahan yang dikelola oleh pemuda tani yang konsisten dikarenakan karena lahannya adalah milik sendiri, sementara 7 orang yang menjawab tidak konsisten karena lahannya sewa atau milik investor atau karena dinggap pertanian sebagai pekerjaan sampingan.

Hal tersebut menunjukkan bahwa di Kelurahan Siwalan, lebih banyak pemuda tani yang tidak konsisten terhadap mata pencahariannya. Mereka banyak yang terpengaruh menjadi TKI ataupun kerja di tempat lain.

\section{Kelurahan Babadan}

Kelurahan Babadan berbatasan dengan Kabupaten Madiun. Populasi pemuda tani yang ada di Kelurahan Babadan adalah sebesar 6 populasi. Dari 6 populasi pemuda tani di Kelurahan Babadan dilakukan wawancara terhadap 3 responden sebagai sampel. Penskoran Kelurahan Babadan terdapat pada Tabel 15.

Tabel 15

Penskoran Kelurahan Babadan

\begin{tabular}{ccc}
\hline No. Responden & Skor & Kategori \\
\hline 52 & 21 & Konsisten \\
53 & 13 & Tidak konsisten \\
54 & 24 & Konsisten \\
\hline
\end{tabular}

Sumber: Data Primer Diolah, 2015

Konsistensi pemuda tani di kelurahan Babadan menunjukkan 2 responden yang konsisten, 1 responden tidak konsisten.Semua lahan yang 


\section{Agriekonomika, ISSN 2301-9948 e ISSN 2407-6260 \\ Volume 5, Nomor 1}

dikelola oleh responden di Kelurahan Babadan adalah lahan pertanian milik orang lain yang disewakan.

Karena letak Kelurahan Babadan yang bersebelahan dengan Kabupaten Madiun terdapat beberapa pemuda tani bekerja di Madiun karena tergiur oleh upah atau gaji yang tinggi sebagai penjaga toko.

\section{Kelurahan Demangan}

Dalam penelitian ini, Demangan merupakan kelurahan yang memiliki jumlah pemuda tani sebanyak 12 orang. Responden yang diambil dalam penelitian adalah 6 orang. Penskoran Desa Demangan adalah sebagai berikut.

\section{Tabel 16}

Penskoran Kelurahan Demangan

\begin{tabular}{ccc}
\hline No. Responden & Skor & Kategori \\
\hline 55 & 14 & Tidak konsisten \\
56 & 23 & Tidak konsisten \\
57 & 12 & Tidak konsisten \\
58 & 22 & Konsisten \\
59 & 24 & Konsisten \\
60 & 25 & Konsisten \\
\hline
\end{tabular}

Sumber: Data Primer Diolah, 2015

Pemuda tani di Kelurahan Demangan yang konsisten berjumlah 3 orang responden.Sementara itu responden tidak konsisten sebanyak 3 orang.Hal ini menunjukkan bahwa di Kelurahan Demangan tingkat konsistensinya terhadap sektor pertanian adalah berimbang.

Berdasarkan pembahasan dari masing-masing kelurahan dapat diketahui bahwa karakteristik wilayah yang berbeda menghasilkan tingkat konsistensi yang berbeda pada pemuda tani.Di wilayah yang banyak menjadi basis TKI seperti Siwalan dan Mojorejo, konsistensi pemudanya terhadap kegiatan disektor pertanian menurun, sehingga banyak yang menjawab tidak konsisten.Hal tersebut dikarenakan sebagian besar lahan pertanian adalah milik investor dan masa tanam hanya satu kali dalam satu tahun.Karena lahan yang dikelola milik investor, maka penguasaan lahan buruh tani hanya lahan yang sempit yang mengakibatkan pendapatan dari hasil pertanian rendah sehingga pemuda beralih ke sektor lain.

Sedangkan di tiga wilayah lain, yaitu Kelurahan Babadan, Demangan, Kemuning cenderung lebih konsisten karena lahan yang dikelola masih luas. Sehingga kegiatan pertanian masih diwariskan ke anak cucunya. Pemuda tani yang telah berkecimpung dengan mata pencahariannya dan tidak memiliki keterampilan akan sulit untuk memperoleh pekerjaan lain yang menjanjikan. Sehingga mereka tetap konsisten untuk bekerja di lahan persawahan.

Dari hasil penelitian dapat diketahui bahwa pemuda tani di Kabupaten Ponorogo yang konsisten adalah pemuda tani yang memiliki penguasaan lahan yang luas $\left(>2.000 \mathrm{~m}^{2}\right.$ ), pendapatan tinggi ( $>$ Rp. 15.000.000,00 per tahun), tidak memiliki keterampilan lain, dan status kependudukan yang merupakan penduduk asli. Sedangkan pemuda tani yang tidak konsisten adalah pemuda yang memiliki penguasaan lahan yang sempit $\left(>1.200 \mathrm{~m}^{2}\right)$, pendapatan dari hasil kegiatan pertanian rendah (< Rp. 10.000.000,00 per tahun), dan mengelola lahan milik investor. 
Berdasarkan hasil penelitian tersebut dapat diketahui bahwa faktor paling dominan yang mempengaruhi konsistensi buruh tani di Kabupaten Ponorogo adalah luas penguasaan lahan, pendapatan, keterampilan lain yang dimiliki, dan status kependudukan. Keadaan tersebut sesuai dengan teori yang dikemukakan oleh Yunus (2008), bahwa konsistensi petani dipengaruhi oleh keterampilan lain dan status kependudukan.

\section{PENUTUP}

Berdasarkan hasil penelitian dan pembahasan mengenai tingkat konsistensi pemuda tani di sektor pertanian Kabupaten Ponorogo, maka simpulan yang dapat diperoleh adalah sebagai berikut bahwa secara keseluruhan dari 60 responden di Kecamatan Kota Ponorogo terdapat 23 pemuda tani yang tidak konsisten, 15 pemuda tani kurang konsisten, dan 22 pemuda tani konsisten. Pemuda tani tersebut tersebar di lima desa yaitu yaitu Mojorejo, Kemuning, Siwalan, Babadan, Demangan Penelitian ini bertujuan untuk mengetahui karena mengelola lahan milik investor.Pemuda tani di Ponorogo yang konsistensinya tinggi adalah pemuda yang berada di Kelurahan Babadan, Kemuning dan DemanganPemuda tani yang konsisten adalah pemuda tani yang memiliki penguasaan lahan yang luas $\left(>2.000 \mathrm{~m}^{2}\right)$, pendapatan tinggi $(>R p 15.000 .000,00$ per tahun), tidak memiliki keterampilan lain, dan status kependudukan yang merupakan penduduk asli. Pemuda tani yang tidak konsisten adalah pemuda tani yang memiliki penguasaan lahan yang sempit $\left(<1.200 \mathrm{~m}^{2}\right)$, pendapatan dari hasil kegiatan pertanian rendah ( $<$ Rp 10.000.000,00 per tahun, dan mengelola lahan milik investor. Harapan kedepan masyarakat di Kecamatan Ponorogo, baik itu masyarakat yang terlibat langsung dalam bidang pertanian maupun masyarakat umum yang tidak terlibat langsung dalam bidang pertanian hendaknya lebih peduli terhadap keadaan lahan pertanian yang semakin menyempit akibat terdesak oleh pembangunan untuk ikut berpartisipasi menjaga lahan pertanian agar tidak terus terdesak oleh pembangunan.Dan khusus bagi masyarakat yang terlibat langsung dalam bidang pertanian hendaknya tetap konsisten dan berusaha meningkatkan produktivitas pertanian dengan menambah pengetahuan tentang pertanian dan mengikuti penyuluhan.

\section{DAFTAR PUSTAKA}

Arvianti, Eri Yusnita. Asnah dan Anung Prasety. 2015. Minat Pemuda Tani Terhadap Tranformasi Sektor Pertanian di Kabupaten Ponorogo. Jurnal Buana Sains 15(2): 181-188.

BPS. 2014. Kabupaten Ponorogodalam Angka Tahun 2014. Badan Pusat Statistik. Indonesia

Departemen Pendidikan Nasional. 2007. Kamus Besar Bahasa Indonesia.Balai Pustaka. Jakarta.

Enoch, Moch dan Triton Pariwara Budi. 2006. Prediksi Erosi Lahan Pertanian. UNESA University Press. Surabaya.

Hamyana. 2014. Preferensi Generasi Muda Di Bidang Pertanian. Jurnal Agriekstensia 13(2): 15-31 
Herlinawati. 2012. Adaptasi Petani pada Banjir Musiman di Desa Mojodadi Kecamatan Kedungpring Kabupaten Lamongan. Skripsi. Surabaya.

Muksi. Amrin Jahi. Margono Slamet dan Djoko Susanto. 2009. Kualifikasi Pemuda Tani Perdesaan di Jawa Timur. Jurnal Penyuluhan 5(1): 36-44.

Nurfu'adah, Ika. 2013. Faktor-Faktor yang Mempengaruhi Eksistensi Petani Gurem di Bantaran Sungai Brantas Kecamatan Kesamben Kabupaten Jombang.Skripsi.Surabaya.

Rauf, Abdul. Rahmawaty dan Dewi Budiati TJ. Said. 2013. Sistem Pertanian Terpadu Di Lahan Pekarangan Mendukung Ketahanan Pangan. Jurnal Pertanian Tropik 1(5) : 1-8.

Yunus, Hadi Sabari. 2008. Dinamika Wilayah Peri Urban.Pustaka Pelajar. Yogyakarta.

Zanses Gilbarto Frofika. I Wayan Suwendra dan Gede Putu A J.S. 2015. Analisis Efektivitas Usaha Agribisnis Perdesaan. e-Jurnal Bisma 3(2): 15-31. 